\title{
Redes de política de educação integral da Paraíba: fluxos e influências neoconseruadoras e neoliberais
}

\author{
Paraíba integral education policy networks: neoconservative and \\ neoliberal flows and influences
}

\section{Redes de la política de educación integral de Paraíba: flujos e influencias neoconseruadoras y neoliberales}

\author{
Ana Cláudia Silua Rodrigues" \\ Universidade Federal da Paraíba, Programa de Pós-graduação em Educação, Departamento \\ de Fundamentação da Educação, Professora. \\ https://orcid.org/0000-0001-6621-1861

\section{Rafael Ferreira de Souza Honorato ${ }^{2}$} \\ Fundação de Desenuolvimento da Criança e do Adolescente Alice de Almeida, área de \\ Educação da Diretoria Técnica, Coordenador. \\ https://orcid.org/0000-0002-6196-0211
}

Resumo: 0 objetivo desta pesquisa foi conhecer as redes de políticas que influenciam a produção da política educacional do Programa Escola Cidadã Integral. As discussões partem das "novas" lógicas e racionalidades da Política de Educação Integral da Rede Estadual de Ensino da Paraíba e suas relações com as redes politicas que pautam a agenda neoconservadora e neoliberal no Brasil. Assim, nosso lócus é o Programa Escola Cidadã Integral, instituído pela Lei estadual n. 11.100/2018. A abordagem foi qualitativa, e o método utilizado foi a etnografia de redes, associado à análise documental. Como instrumento, utilizamos a entrevista semiestruturada com representantes do governo estadual. Os estudos de Bowe, Ball e Gold (1992), Ball (2014, 2013) e Apple (2003) subsidiaram a compreensão sobre as novas formas de governança presentes na política de educação integral e as fontes de autoridades. As análises constataram que a parceria com o Instituto de Corresponsabilidade pela Educação (ICE) possibilitou uma gestão da educação integral com traços neoliberais e neoconservadores a partir da padronização das escolas e da homogeneização dos discentes utilizando o discurso de uma educação de boa qualidade, capaz de formar sujeitos sociais com acesso a oportunidades iguais. Observamos que as bases pedagógicas dessa rede defendem o avanço econômico e o resgate de princípios e valores com vistas a consolidar um currículo que forme para a atuação no mercado de trabalho

Doutora e Mestre em Educação pela Universidade Federal da Paraiba.

Mestre e doutorando pelo Programa de Pós-Graduação em Educação da Universidade Federal da Paraíba. 
e a fortalecer o pensamento que reduz a educação a uma mera apropriação de competências e habilidades sem a formação de sujeitos autônomos, mas subordinados ao capital econômico.

Palavras-chave: Políticas educacionais. Poder. Identidades. Neoconservadores. Neoliberalismo.

Abstract: The objective of this research was to know the policy networks that influence the production of the educational policy of the Integral Citizen School program. The discussions start from the "new" logic and rationality of the Integral Education Policy of the Paraiba State Education Network and its relations with the political networks that guide the neoconservative and neoliberal agenda in Brazil. Thus, our locus is the Integral Citizen School Program, instituted by State Law 11.100 / 2018. The approach was qualitative and the method used was the ethnography of networks, associated with document analysis. As an instrument we used the semi-structured interview with representatives of the state government. The studies by Bowe, Ball and Gold (1992), Ball (2014, 2013) and Apple (2003) supported the understanding of the new forms of governance present in integral education policy and the sources of authorities. The analysis found that the partnership with the Institute of Co-responsibility for Education (ICE) made possible the management of integral education with neoliberal and neoconservative features from the standardization of schools and the homogenization of students using the discourse of a quality education, capable of forming social subjects with access to equal opportunities. We observe that the pedagogical bases of this network defend the economic advance and the rescue of principles and values with a view to the consolidation of a curriculum that forms for acting in the labor market, as well as the strengthening of the thought that reduces the education to the mere appropriation of competences and skills without the formation of autonomous subjects, but subordinated to economic capital.

Keywords: Educational policies. Power. Identities. Neoconservatives. Neoliberalism.

Resumen: El objetivo de esta investigación fue saber las redes de políticas que influyen en la producción de la politica educativa del programa Escola Cidadã Integral. Las discusiones parten de las "nuevas" lógicas y racionalidades de la Política de Educación Integral de la Red de Educación del Estado de Paraíba y sus relaciones con las redes políticas que guían la agenda neoconservadora y neoliberal en Brasil. Por lo tanto, nuestro lugar es el Programa Integral de Escuelas Ciudadanas, instituido por la Ley Estatal 11.100 / 2018. El enfoque fue cualitativo y el método utilizado fue la etnografía de redes, asociada al análisis documental. Como herramienta, utilizamos la entrevista semiestructurada con representantes del gobierno estatal. Los estudios de Bowe, Ball and Gold (1992), Ball (2014, 2013) y Apple (2003) respaldaron la comprensión de las nuevas formas de gobernanza presentes en la politica educativa integral y las fuentes de las autoridades. Los análisis encontraron que la asociación con el Instituto de Corresponsabilidad para la Educación (ICE) permitió la gestión de la educación integral con rasgos neoliberales y neoconservadores a partir de la estandarización de las escuelas y la homogeneización de los estudiantes utilizando el discurso de la educación de calidad, capaz de formar sujetos sociales con acceso a la igualdad de oportunidades. Observamos que las bases pedagógicas de esta red defienden el avance económico y el rescate de principios y valores con miras 
a consolidar un currículo que se forme para actuar en el mercado laboral, así como al fortalecimiento del pensamiento que reduce la educación a la mera apropiación de habilidades y habilidades sin la formación de sujetos autónomos pero subordinados al capital económico.

Palabras clave: Politicas educativas. Poder. Identidades. Neoconservadores. Neoliberalismo

Recebido em 19 de agosto de 2019 Aceito em 28 de maio de 2020

Publicado em 10 de junho de 2020

\section{INTRODUÇÃO}

Neste artigo, apresentamos as redes de políticas que influenciam a produção da política educacional para a Educação Integral na Paraiba, especificamente o programa que institucionalizou as Escolas Cidadãs Integrais, ${ }^{3}$ por meio do Decreto n. 36.409/2015 (PARAÍBA, 2015b), e as Escolas Cidadãs Integrais Técnicas, com o Decreto n. 36.408/2015 (PARAÍBA, 2015a), publicados no Diário Oficial do Estado da Paraíba em 1 de dezembro de 2015. Posteriormente, transformou-se em programa com a publicação da Medida Provisória n. 267, em 7 de fevereiro de 2018 (PARAíBA, 2018b), que instituiu o Programa de Educação Integral, composto de Escolas Cidadãs Integrais (ECI), Escolas Cidadãs Integrais Técnicas (ECIT) e Escolas Cidadãs Integrais Socioeducativas (ECIS), instituiu o Regime de Dedicação Docente Integral (RDDI) e deu outras providências, tornando-se a Lei n. 11.100, em 6 de abril de 2018, retificada pela ementa de Lei n. 11.314, de 11 de abril de 2019.

A nova redação da Lei n. 11.100 (PARAíBA, 2018a) instituiu o Programa de Educação Integral e o Regime de Dedicação Docente Integral (RDDI), vinculado à Secretaria de Estado da Educação e da Ciência e Tecnologia (SEECT), e inseriu o Centro de Referência em Inovação da Aprendizagem (CRIA) ${ }^{4}$ como mais um modelo pedagógico da política em tela voltado para o Ensino Fundamental.

Também apresenta que o objetivo do programa é "[...] planejar e executar um conjunto de ações inovadoras em conteúdo, método e gestão, direcionado à melhoria da oferta e qualidade do ensino na Rede Pública Estadual." (PARAíBA, 2019, p. 1). 0 documento

3 Projeto submetido e aprovado pelo Conselho de Ética da instituição, através do site Plataforma Brasil, sob número de protocolo 89196018.8.0000.5188.

4 Segundo a Lei n. 11.314/2019, entende-se por CRIA “.... escola de ensino Fundamental - Anos Iniciais - em período integral, com método didático e administrativo próprios, conforme regulamentação, observada a base nacional curricular comum, tendo conteúdo pedagógico voltado para formação de indivíduos protagonistas e conscientes de seus valores sociais direcionados ao pleno exercício da cidadania." (PARAlíBA, 2019, p. 2). 
estabelece que o Programa de Educação Integral pode ser aplicado a todas as etapas e modalidades de ensino estabelecidas na Lei de Diretrizes e Bases da Educação Nacional (LDBEN).

A ementa de Lei n. 11.314/2019 também alterou a redação referente aos objetivos gerais e específicos das ECI, ECIT, ECIS e CRIA. De acordo com seu Artigo $3^{\circ}$ :

São objetivos das escolas que compõem o Programa de Educação Integral: I - objetivos gerais:

a) ofertar ensino integral para todas as etapas de ensino da educação básica;

b) formar cidadãos solidários, socialmente ativos e competentes;

c) desenvolver aptidões individuais dos estudantes;

d) conscientizar os estudantes acerca de suas responsabilidades individuais e sociais; e,

e) proporcionar um ambiente de aprendizagem interdimensional.

\| - objetivos específicos da ECl, ECIT e ECIS:

a) desenvolver processos formativos para fomentar o protagonismo juvenil; b) prover as condições para a redução dos índices de evasão escolar, de abandono e de reprovação, bem como acompanhar a sua evolução no âmbito das escolas em tempo integral;

c) ampliar o Índice de Desenvolvimento da Educação Básica - IDEB, tanto no componente de fluxo quanto no de proficiência, de acordo com as metas estabelecidas no Plano de Ação da Secretaria de Estado da Educação e da Ciência e Tecnologia; e,

d) aplicar metodologias, estratégias e práticas educativas inovadoras introduzidas e consolidadas pela equipe de implantação do Programa de Educação Integral, assegurando aos estudantes as condições para a construção dos seus Projetos de Vida. (PARAÍBA, 2019, p. 1, grifo nosso).

Como estratégia para que as escolas alcancem esses objetivos, 0 art. $4^{\circ}$ da lei supracitada organiza o currículo em seu espaço/tempo no período escolar integral, nos turnos da manhã e da tarde, que corresponde a "[...] 9 (nove) aulas, de 50 (cinquenta) minutos cada, e jornada total de 7 (sete) horas e 30 (trinta) minutos por dia, na ECI, ECIT e ECIS; e período escolar diário composto por 7 (sete) aulas, de 60 (sessenta) minutos cada, e jornada de 7 (sete) horas por dia no CRIA." (PARAÍBA, 2019, p. 2). Nessa mesma direção, o art. 5, que trata do Regime de Dedicação Docente Integral (RDDI), institui uma carga horária semanal diurna de 40 horas para professores, diretores e coordenadores pedagógicos e administrativos em todas as instituições que fazem parte do programa, com exceção de professores contratados em regime especial para lecionar nos cursos técnico, profissionalizante e/ou componentes da parte diversificada do currículo. A carga horária dos professores é organizada de forma que cumpram 28 horas em sala de aula ou em atividades multidisciplinares e $१ 2$ horas dedicadas a estudos e planejamento. 
A SEECT, por meio da Comissão Executiva de Educação Integral (CEEl), composta pela equipe de implantação do Programa nas ECI, ECIT e ECIS, e da Comissão Executiva de Educação Integral para o Ensino Fundamental - Anos Iniciais (CEElEF), composta pela equipe de implantação do Programa nos Centros de Referência em Inovação da Aprendizagem, é responsável por definir a matriz curricular para a rede que compõe o Programa de Educação Integral. Por diretrizes operacionais entendem-se os "[...] instrumentos que visam orientar acerca da operacionalização das rotinas escolares e subsidiar a organização das atividades desenvolvidas pela equipe escolar [...]" (PARAíBA, 2019, p. 2).

Na emenda feita na Lei n. 11.100/2018, o art. 21 trata sobre a composição das comissões executivas e pontua que ambas são "[...] formadas por profissionais e especialistas em educação e/ou personalidades públicas reconhecidas por sua atuação e relevante contribuição na área da Educação [...." (PARAIBA, 2019, p. 3), com o objetivo de

I - aprovar e acompanhar o desenvolvimento dos Planos de Ação, assegurando o cumprimento dos critérios, alcançado as metas pactuadas, e divulgando os resultados;

|l - acompanhar e assegurar o cumprimento do calendário escolar da $\mathrm{ECl}$, ECIT, ECIS e do CRIA, bem como da Agenda Bimestral;

III - acompanhar a execução dos projetos desenvolvidos na ECl, ECIT, ECIS e no CRIA;

IV - propor e apoiar a definição das Unidades de Ensino que participarão da rede das Escolas Cidadãs Integrais, Escolas Cidadãs Integrais Técnicas e da Rede de Centros de Referência em Inovação da Aprendizagem de acordo com as metas e as diretrizes politicas administrativas e financeiras da Gestão Estadual;

V - estabelecer metas de desempenho da ECI, ECIT, ECIS e do CRIA em consonância com o sistema de avaliação estadual e nacional e seus respectivos Planos de Ação;

$\mathrm{VI}$ - realizar, anualmente, a avaliação de desempenho dos docentes, bem como de cada membro da equipe gestora da escola e recomendar ações a partir dos seus resultados. 0 detalhamento da avaliação de desempenho será publicado e regulamentado em Portaria pelo Secretário Estadual de Educação e da Ciência e Tecnologia;

VII - formular a política de educação Integral no âmbito da Secretaria Estadual de Educação e da Ciência e Tecnologia;

VIII - implantar as inovações em conteúdo, método e gestão;

IX - acompanhar e rever, caso necessário, o desenvolvimento dos Planos de Ação da ECl, ECIT, ECIS e do CRIA;

$X$ - acompanhar os Programas de Ação da Direção da ECl, ECIT, ECIS e do CRIA;

XI - apoiar o Secretário de Estado da Educação e da Ciência e Tecnologia no planejamento para a expansão de ECI, ECIT, ECIS e do CRIA e definir padrões básicos de funcionamento de ECI, ECIT, ECIS e do CRIA. (PARAíBA, 2018a, p. 6). 
Ressalte-se, no entanto, que as normativas em vigência não explicitam o contexto em que a Política de Educação Integral na Paraíba foi constituída, principalmente quais redes foram responsáveis por influenciar a criação e a organização pedagógica e de gestão dessa nova proposta educacional. Rodrigues (2019) apresenta as linhas gerais da proposta curricular do programa e indica que ele atende parcialmente à formação dos jovens e infere que a experiência implantada assume características de educação de tempo integral, e não de educação integral. Neste trabalho, não observamos as discussões sobre as redes de políticas que originaram a proposta educacional.

Carvalho e Rodrigues (2019, p. 4263), ao estudarem a privatização da educação pública na Paraiba, vincularam a atuação do Instituto de Corresponsabilidade pela Educação (ICE) ao que denominaram de "[...] geografia política da educação [...]", por compreenderam que "a articulação multiescalar do território em rede do ICE está transformando a educação pública no Brasil e na Paraíba." Explicitam, ainda, que o "[...] estudo dá ênfase ao caráter relacional das esferas econômica, cultural e política, entre empresas privadas, Estado e educação pública [...]" (CARVALHO; RODRIGUES, 2019, p. 4264).

No texto citado, os autores afirmam que o ICE articula "[...] uma complexa rede de atuação seguindo as orientações do neoliberalismo mundial - sobretudo pelo Banco Mundial e UNESCO [...]" (CARVALHO; RODRIGUES, 2019, p. 4266). Para os autores, "[...] as ações do ICE se consolidam na realidade da população brasileira através da educação pública [...] (CARVALHO; RODRIGUES, 2019, p. 4266-4267). Como visto, existem redes políticas interessadas em atuar na educação integral na Paraíba. Por essa razão, argumentamos que essas novas relações vêm contribuindo para a formulação de políticas nas relações sociais e culturais, criando uma proposta educacional voltada para atender a interesses econômicos e mercadológicos. Para Süssekind (2018, p. 8), é esse "[...] tsunami neoliberal global de fortes tendências conservadoras que inspira retrocessos (inclusive legais) em todos os campos da sociedade, entre eles, uma espécie de reformismo da educação."

Assim, iniciamos nossas discussões definindo o que compreendemos por neoconservadorismo e neoliberalismo, porque esses conceitos apresentam múltiplos significados na literatura e no ideário político social. 0 termo conservadorismo tem sido utilizado com muita frequência nos últimos anos, porém, para Bonazzi (2000), a compreensão de seu significado dependerá de sua utilização como adjetivo ou substantivo, porque é mais fácil entender o que é ser conservador do que o conservadorismo em si, por causa da dificuldade de determinar sua natureza e seus fins.

Neste texto, inicialmente, reportar-nos-emos às formulações elaboradas por Burke (1982) sobre conservadorismo, ao se contrapor aos acontecimentos ocasionados a partir da Revolução Francesa, que defende a finitude humana e a limitação do poder político, que deve ser controlado, principalmente, pelas leis, para estabilizar as ações sociais. Por isso, 
o conservadorismo é considerado uma forma de manutenção sociopolítica dos modos como os sistemas político, social e cultural funcionam, operacionalizado por meio de ideias e atitudes que creem na realização humana em sociedade subordinada à vontade divina. 0 Estado e a sociedade constituem uma organização natural eterna divinamente estabelecida, por isso buscam preservar a ordem e as tradições.

Contrapondo-se à situação política, econômica e social francesa do século $\mathrm{XVIII}$, as ideias progressismas ${ }^{5}$ reivindicavam o protagonismo humano para melhorar seu conhecimento, que, por meio da evolução da ciência, transformaria a natureza para promover seu objetivo maior, que seria o de encontrar a felicidade. Como resultado, surge uma mudança na perspectiva histórica de compreender que o homem poderia ser melhor se fosse cada vez mais racional (BOBBIO; MATTEUCCI; PASQUINO, 2000).

Ao longo dos séculos, essas duas posições se seguiram. Enquanto o progressismo se baseou no tripé ciência, democracia e a perspectiva histórico-materialista para promover o progresso humano e conduzir a sociedade, ampliando o acesso cada vez maior das massas à política e ao consumo, o Conservadorismo foi se transformando e encontrou na possibilidade de educar as massas, na ordem, uma pauta comum aos dois movimentos que também se aproximaram por meio da defesa do desenvolvimento econômico social (BOBBIO; MATTEUCCl; PASQUINO, 2000).

Ao estudar o Movimento Conservador Norte-americano da década de 1950, Vidal (2013), a partir das percepções sobre sociedade, economia e política externa, aponta o pensamento de Kirk (1953) como o edificador da essência conservadora que se expressaria naquele país, principalmente com a preservação da tradição moral da humanidade, e o responsável pelos seguintes pilares que constituíram a síntese desse pensamento: a crença de que existe uma orientação divina que governa a sociedade; a propensão pela tradição; a certeza de que a sociedade civilizada necessita de ordem e de classes, por isso a igualdade que nos une é a moral; a convicção de que a liberdade e a propriedade são inseparáveis; a ideia de que a tradição e os preconceitos sadios são necessários para conter o impulso anárquico do homem; e a necessidade de as mudanças sociais serem lentas (KIRK, 1953 apud VIDAL, 2013, p. 7-8).

É a partir da difusão desses novos princípios da década de 1950, nos Estados Unidos, e da crença de que as ideias do passado devem nortear o pensamento hoje, que Goldwater (2009) argumenta que cada ser humano é responsável pelo próprio desenvolvimento, que deve estar condicionado à liberdade e à ordem. Para Vidal (2013), esses autores não lograram êxito em formular um conservadorismo homogêneo, mas são responsáveis por

Termo "ambíguo e complexo" utilizado por Bobbio, Matteucci e Pasquino(2000) ao se referirem ao movimento que polariza com o Conservadorismo na sua origem. 
questionar a sociedade e estabelecer os princípios fundamentais conservadores com relação à política econômica naquele momento: "defesa de um governo limitado, segurança para a propriedade privada e ênfase na liberdade econômica." (VIDAL, 2013, p. 273).

Para este estudo, é importante registrar que, a partir do século XXI, o conservadorismo passou a pregar a liberdade como uma responsabilidade individual que dela advém. Essa nova roupagem foi denominada de Neoconservadorismo. Entre as mudanças que marcam esse movimento no século XXI está o estreitamento dos direitos civis e sociais como forma de cercear as diferenças, subjugando-as aos padrões instituídos como verdades absolutas, ou seja, aos códigos sociais hegemônicos.

Com o advento do lluminismo e das revoluções burguesas europeias, surgiu, no século XVIII, um movimento que se contrapôs ao governo monárquico e suas formas de controle social: o liberalismo. Por meio da constituição de uma teoria política, econômica e social, esse movimento defendia a livre e ampla concorrência no mercado sem o controle do Estado, a liberdade de comércio, a propriedade privada e a liberdade individual.

Ressalte-se, porém, que o liberalismo não foi um todo unificado. Ao longo dos anos, suas ideias foram se conduzindo a dois tipos principais: o liberalismo dos reformistas sociais e os partidários da liberdade individual. Porém, as mudanças externas, durante a longa fase de industrialização e urbanização, que empreenderam profundas modificações sociais, as políticas intervencionistas de uma parte dos governos liberais e as tensões internas advindas dessas principais correntes liberais instalaram uma "crise do liberalismo" entre os anos de 1880 e 1930 (DARDOT; LAVAL, 2016).

A crise do liberalismo, como ficou conhecida, desencadeou entre os defensores do movimento algumas tentativas de renovação. Destacam-se as ideias de Rougier e Leppmann discutidas durante o Colóquio Walter Lippmann, em 1938, realizado em Paris, principalmente as críticas à forma como as ações do próprio Movimento Liberal contribuíram para seu colapso. Foi durante a realização desse congresso que o referido movimento teve suas bases rediscutidas e aprofundadas, o que gerou uma nova denominação: neoliberalismo.

Para Lippmann, o neoliberalismo deve suprir os problemas de adaptação do liberalismo à revolução permanente dos métodos e das estruturas de produção que criam novas formas de dividir o trabalho. Todavia, isso só será possível caso se instaure um novo tipo de vida. Segundo Dardot e Laval (2016, p. 91), para que o movimento neoliberal se adeque às novas demandas, é necessária "uma verdadeira política da condição humana nas sociedades ocidentais", o que, para os autores, só será possível por meio de uma política global de adaptação à competição: a eugenia e a educação.

Uma politica voltada para educar as massas é essencial para essa nova fase de adaptação do liberalismo. É preciso que a população tenha acesso a uma educação que se 
adeque às novas técnicas, à concorrência generalizada, à empregabilidade, ao protagonismo e à performatividade. Spring (2018) refere que foi a partir da submissão da educação à economia, nas décadas de 1940 e 1950, nos Estados Unidos, com o apoio da Escola de Chicago, que as ideias sobre a necessidade de investir no capital humano para melhorar o crescimento da economia se constituíram.

Observa-se que o raciocínio econômico sobre os assuntos da vida resultou em medições da contribuição das escolas e da família para melhorar a economia e a produtividade. Autores como Becker, Friedman, Schultz e Heckman são expoentes do pensamento da livre escolha, da moldagem do caráter, do seu conhecimento e de suas habilidades para as demandas do mercado de trabalho e os desejos das corporações internacionais (SPRING, 2018). A aplicação da teoria da racionalidade (Rational choice theory) por esses economistas da Escola de Chicago na vida humana continua a influenciar políticas educacionais globais até hoje.

Todavia, apesar de serem dois movimentos distintos, houve mudanças no cenário internacional e no nacional, como, por exemplo, a aprovação do Brexit, na Inglaterra; a vitória de Donald Trump, nos Estados Unidos; as eleições na França, na Alemanha, na Áustria e, recentemente, na Tchecoslováquia, e a tendência neoliberal associada ao neoconservadorismo. No Brasil, os projetos da reforma trabalhista da previdência, a Escola sem Partido, os ataques que vários estudiosos, nacionais e internacionais, sofreram, como a filósofa americana, Judith Butler, denotam a atuação desses movimentos de forma efetiva.

Assim, temos como principal característica da união desses dois movimentos, que formam a nova direita, o liberalismo das relações do, no e com o mercado, com um foco central na contratação da força de trabalho e regulação sobre a vida privada. Esse é o contexto que designamos como a nova configuração neoconservadora, cujo modus operandi é associado ao neoconservadorismo como forma de fortalecer o liberalismo do mercado e as relações que desenvolvemos com ele e garantir o resgate e a manutenção dos modelos conservadores de sociedade e cultura.

Apple (2003), ao analisar as novas configurações que as agendas conservadoras e neoliberais (que ele denominou de modernização conservadora) vêm impondo às escolas, principalmente nos países da Europa e nos Estados Unidos, reflete sobre a seriedade da definição do que deve ou não ser ensinado nas instituições de ensino. Os argumentos principais utilizados pelos que defendem a necessidade de a escola se "libertar" das "imposições ideológicas" se justificam por se compreender que a educação deve transmitir um conhecimento "neutro", que atenda à formação dos estudantes para o mercado de trabalho. Essa assertiva conceitual sobre os fins da educação é a principal disputa estabelecida na arena dos confrontos políticos e culturais atuais que configuram as relações de poder na sociedade. 
A partir dessas considerações, nossas questões de pesquisa foram: que redes políticas estão atuando, por meio do Instituto de Corresponsabilidade pela Educação, no Programa Escola Cidadã Integral, desenvolvido pelo Governo do Estado da Paraíba? É possível identificar as ideias e as orientações internacionais e nacionais vinculadas às perspectivas neoliberais e neoconservadoras no referido programa?

Nesses termos, o pressuposto de Ball (2010) de que, a cada dia, a Educação está mais sujeita à mercantilização e à privatização, o que é uma característica da política global de educação desenhada para o século XXI, remete ao fato de que há possibilidade de que a Educação Integral, ao assumir a centralidade quanto à responsabilidade de elevar a qualidade da educação pública, tenha se tornado atrativa para os interesses do mercado e o foco central na manutenção dos modelos neoconservadores.

Assim, mapear e categorizar os diferentes tipos de envolvimento do setor privado e os discursos conservadores presentes na organização de tal política, para saber quais são as empresas e os interesses que elas representam na organização da política de Educação Integral, é uma forma de potencializar as análises da política em tela, ao levar em consideração as novas formas de governança em rede e seus impactos (inter)nacionais sobre a reforma educacional, a democracia, a oportunidade social, a igualdade e o significado e a prática da educação integral.

Como marco, estamos estabelecendo o fortalecimento da agenda que deu ênfase à crescente discussão sobre a "educação integral" no Brasil desde 2007, como "um caminho para garantir uma educação pública de qualidade." (GOUVEIA, 2006, p. 84). Nesse ano, o Ministério da Educação (MEC), por meio da Secretaria de Educação Continuada, Alfabetização e Diversidade (SECAD), emitiu um convite oficial para as instituições de base de educadores e gestores, como: Undime, Consed, CNTE, Anfope e Universidades, além de entidades da sociedade civil organizada e ONGs ligadas (in)diretamente à educação, para que, juntas, elaborassem um texto de referência para promover o debate nacional sobre esse modelo de educação, que resultou na elaboração do Compromisso Todos pela Educação.

Consideramos, contudo, que esse marco está estreitamente relacionado às experiências que marcaram a organização do sistema educacional do Brasil no que concerne aos significados e às práticas de Educação Integral no século XX, como o Centro Educacional Carneiro Ribeiro (CECR) (1940-1960), de Anísio Teixeira, os Centros Integrados de Educação Pública (CIEPs) (1980-1990), de Darcy Ribeiro, os Centros Integrados de Atendimento à Criança (CIACs), no Governo de Fernando Collor (1990-1992), e os Centros de Atenção Integral à Criança (CAICs), durante o Governo de Itamar Franco (1992-1994).

É necessário, no entanto, considerar que cada uma dessas políticas parte de interesses diferentes e assume sentidos distintos no tempo e no espaço em que foram 
pensadas. Bomeny (2009) destaca a diferença que existia entre a proposta de Anísio Teixeira e a de Darcy Ribeiro, apesar de ambas terem como foco as classes populares. 0 primeiro pautava seu projeto como um modelo pedagógico, e o segundo tinha um cunho políticosociológico. Para além desse aspecto, a experiência de Anísio Teixeira tinha como principal responsável por manter a política, o Estado. Já Darcy Ribeiro, dentro de um processo histórico de redemocratização e abertura ao mercado internacional, deu ao seu projeto feições neoliberais que se coadunam com a criação de outros projetos educacionais cujos parceiros eram organizações não governamentais, instituições filantrópicas e, em alguns casos, o voluntariado, que se aproxima da experiência que o movimento de Cidades Educadoras defendia.

Por isso, nosso objetivo consistiu em conhecer as redes de políticas que influenciam a produção da política educacional do Programa Escola Cidadã Integral, presentes em 153 escolas do Estado da Paraíba em 2020. 0 texto foi organizado em três seções, além da introdução e das considerações: na primeira, situamos o leitor sobre as redes de políticas educacionais; na segunda, apresentamos a perspectiva metodológica da pesquisa; e na terceira, os fluxos e as influências da rede de educação integral na Paraiba. No final, tecemos nossas considerações acerca da pesquisa.

\section{INFLUÊNCIAS, FLUXOS E REDES DE POLÍTICAS EDUCACIONAIS}

Para coletar os dados, utilizamos o método da etnografia de rede como estratégia da pesquisa qualitativa que, segundo Ball (2014), tem o objetivo de utilizar as formas de comunicação virtual e eletrônica como ferramentas que possam nos fornecer um rico e mais amplo acesso ao campo social por meio das redes sociais, associadas a outros dados que podem dar ênfase aos fluxos e às mobilidades do capital, das pessoas, das ideias e das políticas.

Depois de uma busca extensa na internet por iniciativas privadas que, direta ou indiretamente, vêm constituindo redes que estão disputando a significação da política de educação integral no Brasil, por meio do processo de terceirização da educação, reunimos um número de 50 páginas da internet, 20 vídeos, 10 apresentações em PowerPoint, um blog, 16 manuais e textos que compõem os dados utilizados neste estudo.

Estrategicamente, também usamos duas entrevistas semiestruturadas realizadas com membros do governo que estavam presentes, em 2015, durante a gênese da Política de Educação Integral no Estado da Paraíba, já que ambos participaram da elaboração e da atuação da política desde sua fase mais embrionária. Isso nos auxiliou a refletir sobre uma 
questão central para a qual Ball (2014) chama a atenção sobre a necessidade de demonstrar os efeitos das redes e seu trabalho nos processos da política analisada. Esses entrevistados foram essenciais no processo de produção da política e da constituição da rede, por atuarem, na época, um como governador, e o outro como secretário de educação do Estado.

Para fins de análise, ancoramo-nos na abordagem do Ciclo Contínuo de Políticas de Bowe, Ball e Gold (1992), que consideram a natureza complexa e controversa da política. Desenvolvemos nossas inferências com foco na formação do discurso sobre a Política de Educação Integral na Paraíba. Para isso, utilizamos o recorte do contexto de influência que, para Bowe, Ball e Gold (1992), é onde geralmente a política é iniciada, onde os grupos interessados lutam para influenciar a definição do que é ser educado e o papel social da educação. É aqui que os discursos se fundem.

Esse contexto é composto de arenas públicas e privadas, dentro e ao redor de partidos políticos, governo e processo legislativo, que constituem o novo modelo de governança que, por meio das redes de políticas responsáveis por influenciar o processo de organização de uma política, desenvolve conceitos-chaves que, quando legitimados, formam um discurso que serve como base para a política. Esses discursos podem ganhar apoio, mas também podem ser contestados na arena da ação pública por comitês, órgãos nacionais e grupos representativos, principalmente pelos meios de comunicação, entre outros, que servem como lugar de articulação e influência.

Nesse sentido, nossas análises foram pautadas em dois momentos: $\circ$ primeiro consistiu em mapear as redes de política e identificar os grupos que estão disputando a influência da política em tela, para entendermos os fluxos de ideias que vêm sendo propagadas pelas redes internacionais e nacionais e se houve mobilidade da política e identificar os grupos e/ou sujeitos que ofereceram soluções por meio dos mercados acadêmico e político. 0 segundo momento consistiu em analisar temas referentes a financiamento e às soluções, às recomendações e/ou às imposições de organismos multilaterais.

Segundo Ball (2014), as redes de políticas são constituídas de sujeitos e/ou organizações que se unem em torno de interesses, implícitos ou não, em comum, mediante iniciativa própria ou indução de governos ou agências multilaterais, construindo e disseminando informações com mecanismos adequados, que servem como canais de informação. Essas redes servem como arenas, no campo do contexto da influência, capazes de proliferar formas de pensar e de agir politicamente. Essa unificação tem o objetivo de fortalecer os discursos dos grupos envolvidos, ampliando sua capacidade de alcançar a constituição do discurso em torno de suas causas. 


\section{REDES DE POLÍTICA E OS NOUOS MODOS DE GOUERNANÇA}

0 termo redes tem sido um conceito e/ou método utilizado por inúmeras ciências, como a Psicologia Social, a Sociologia, a Informática, entre outros, como gestão intergovernamental, como um modelo estratégico de gestão de políticas ou como um novo modelo de governança que institui relações não hierárquicas entre o local e o global (FLEURY, 2005). Todavia, Börzel (1997) adverte que alguns autores têm operado com as redes como forma de representar a multiplicidade de atores envolvidos nas políticas, enquanto outro grupo a utiliza como uma ferramenta analítica das relações entre os atores e o poder público. Há, ainda, os que entendem as redes de políticas como um método de análise da estrutura social.

No Brasil, as pesquisas em Educação têm utilizado as redes como abordagem teórico-metodológica para "pesquisar, descrever e visualizar relações de governança" (BALL, 2014, p. 32), principalmente depois da tradução da obra de Ball (2014), Educação Global SA: novas redes políticas e imaginário neoliberal, como, por exemplo, Shiroma (2014). Anterior ao processo de tradução, a discussão sobre as redes era fomentada por um conjunto de resenhas produzidas por grupos de pesquisadores que utilizam as teorias de Ball para a pesquisa em educação. Podemos citar como principais resenhas Honoraro et al. (2019) e Marcondes, Freun e Leite (2017). Esses estudos usaram a abordagem que teve origem na Grã-Bretanha, que considera as redes políticas como parte das relações intergovernamentais e pressupõe que "a existência de uma rede de políticas, ou, mais particularmente, de uma comunidade política, delimita a agenda política e dá forma aos resultados da política." (RHODES, 1986, 1988; MARSH; RHODES, 1992, p. 197).

Ao introduzir na discussão as redes de políticas, considerando-as como arranjos contingentes de organizações que estão envolvidas em diferentes níveis na coordenação, na gestão e no controle da política, em constante interação e tensão, precisamos trazer para o diálogo a nova governança (BALL, 2014) como uma transformação na forma de compreender a ação de governar exclusivamente do Estado e de superar a visão monolítica, para chegarmos a uma pluricêntrica, em que a governança, de forma descentralizada, constitui-se a partir de redes compostas de múltiplos "atores".

Nesse sentido, podemos considerar que as redes políticas traçam linhas tênues entre o Estado e a Sociedade e facilitam para que os jogos de poder com interesses particulares intervenham no processo de formulação das políticas (SCHNEIDER, 2005; SANTOS, 2005), o que nos leva a questionar a função do Estado na elaboração e na intermediação dos diferentes interesses impressos nas políticas educativas em um contexto marcado pela globalização econômica, o que aumenta a influência dos atores do mercado e a crescente onda neoconservadora que fortalece agendas pautadas, principalmente, em padrões hegemônicos de família, religião, sexo e gênero. 
Assim, o que se constitui é, segundo Ball (2014), uma "governança em rede", como forma de institucionalizar as relações de poder, para tratar as políticas públicas em situações que, aparentemente, são impossíveis de resolver. Para isso, surgiu esse novo modo de governar, por meio da colaboração, da parceria e do trabalho em rede, com vistas ao método compartilhado para resolver o problema e dar oportunidade a outros atores para que participem do trabalho de governança, a fim de produzir políticas eficazes e legítimas e de construir novos e abrangentes mecanismos de controle, mas que têm a sutileza como característica central. Ball, Maguire e Braun (2016) trazem como exemplo desses mecanismos as tecnologias de avaliação das políticas.

Esse processo de otimização, por meio da catalização de setores - público, privado e voluntário - na busca por resolver problemas da sociedade, ao mesmo tempo em que dá uma sensação de flexibilidade para realizar ajustes nas complexas condições existentes no Estado, tem se configurado para os atores sociais e econômicos como uma estratégia que limita a resistência e a inovação. Todavia, não tem afastado a falta de êxito das políticas (BALL, 2014).

Isso gera, no contexto de influência, uma expansão de arenas em que as redes passam a disputar a significação da política, que institui, por meio dessa proliferação, uma opacidade quanto à elaboração da política, o que não deixa claras as pautas e quem as defende e quais grupos e interesses a política representa, ou seja, a privatização da política (BALL, 2014). 0 exercício analítico que realizamos no tópico seguinte pretende entender a política que se encontra nos bastidores de forma a refletir sobre os grupos que compõem as redes, os financiadores e os interesses presentes na Política de Educação Integral.

\section{FLUXOS E INFLUÊNCIAS NA POLÍTICA DE EDUCAÇÃO INTEGRAL DA PARAIIBA}

Uma das primeiras constatações que fizemos no desenvolvimento da pesquisa foi que, nas últimas décadas, foram ensaiadas múltiplas iniciativas ligadas à Educação Integral, com o discurso de promoção de educação de boa qualidade. Nesse sentido, destacam-se o Plano de Desenvolvimento da Educação (PDE), Todos Pela Educação (TPE) e o Programa Mais Educação (PME). 0 PDE tem como objetivo prover recursos para a educação. A administração desses recursos envolve os pais, a comunidade, os professores, os alunos e os gestores. A TPE é uma organização da sociedade civil que informa, em sua página na internet, que não tem fins lucrativos, é plural, suprapartidária e independente - não recebe recursos públicos. Tem como propósito "[...] melhorar o Brasil, impulsionando a qualidade e a equidade 
da Educação Básica no País L...]" (TODOS PELA EDUCAÇÃO, 2020). Já o PME visa articular as políticas sociais com a implementação de ações educativas para crianças, adolescentes e jovens (BRASIL, 2010).

Na Paraiba, o Programa de Educação Integral vinculado ao Governo do Estado começou a ser pensado em 2015 e se efetivou em 2016. 0 objetivo era melhorar a educação no âmbito da gestão, da estrutura, da organização pedagógica e curricular, das rotinas, dos índices, do acesso, da permanência, da promoção; em outras palavras, "principalmente na acomodação das pessoas que não conseguiam ver educação alguma, ou uma grande parte mais do que uma merenda ruim, né? $E$ de uma relação interna que não movimentava absolutamente o interesse de ninguém." (Entrevistado 1, informação verbal).

Nesse caso, a emergência da política se deve à necessidade de "uma mudança de conteúdo [..] para que a pessoa pudesse estimular através da educação para a vida, não é para a educação, é para a vida, então a coisa pra educação integral [...] ela veio dessa percepção do real, do concreto." (Entrevistado 1, informação verbal). Mas, ao delinear a necessidade de mudar, - Entrevistado revela a tendência de recuperar o passado e estimular o futuro.

A tendência que é apontada na fala do Entrevistado 1 mostra uma forte perspectiva neoconservadora, marcada por lutas que buscam controlar a forma de linguagem e definir limites firmes em torno da construção de um conjunto de regras que instituem os marcadores de identidade, fortalecendo as bases para a regulação moral e social. Para isso, é resgatado um passado imaginário de qualidade social na educação, como uma influência civilizadora que deve servir de modelo e de guardião para o futuro. "Os neoconservadores veem seu papel, por um lado, na mobilização de passados que podem ser aceitos com aprovação e, por outro, na neutralização de passados que só provocaram críticas e rejeições." (HABERMAS, 1985, p. 91).

0 Entrevistado 1 afirma que o primeiro mandato do PSB, na Paraiba (2011-2014), dedicou os três primeiros anos a "....] recuperar a estrutura e incluir uma coisa chamada [...] estímulo ao estudante, protagonismo." (informação verbal). Todavia, elenca que existiram dificuldades para

[...] fazer circular isso dentro da escola [...] dificuldades entre professores, dificuldades maiores ainda entre direções, porque não existia o respeito ao projeto central [...] é o nivel de autonomia, é da dita autonomia, era um negócio que se perdia no tempo, que se diluía e cada um era uma autonomia, se cada um é autonomia você não tem politica pública [...] então a gente passou três anos trabalhando, começando a incluir muito protagonismo juvenil, arte e cultura pra poder começar a sensibilizar [...] o programa de escolas integrais. (Entrevistado 1, informação verbal). 
É importante destacar que, em 2014, já existia o interesse em iniciar a experiência de Educação Integral na Paraíba, mas, como relata o Entrevistado 1, como era um ano eleitoral, não seria propício. Então, em 2015, com a vitória de Ricardo Coutinho para cumprir seu segundo mandato, representantes do Instituto de Corresponsabilidade pela Educação (ICE) visitaram a Paraíba para oferecer seus serviços e convidaram representantes do Estado para conhecer a experiência da educação de Pernambuco, "[...] porque Pernambuco já tinha uma experiência e porque nós fomos procurados [...] porque Pernambuco é a melhor experiência ou a maior no Brasil. Pernambuco tem mais de 50\% dos alunos do ensino médio, vem desde 2007. (Entrevistado 1, informação verbal).

Parece-nos que as premissas de resgatar os tempos áureos da Educação Básica paraibana foi algo que encontrou seus vínculos com o projeto do ICE, que tem como objetivo resgatar o padrão de excelência. Para isso, o ICE, em seu site, elenca como necessidade a "aplicação de inovações em conteúdo, método e gestão, objetivando a formação integral do jovem nas dimensões pessoal, social e produtiva." (INSTITUTO DE CORRESPONSABILIDADE PELA EDUCAÇÃO, [20--2], p. 12).

Com efeito, a implementação da Educação Integral se tornou o terreno para a luta política pela determinação dos sistemas básicos de mensagens educacionais (BERNSTEIN, 1971): currículo, avaliação e, mais recentemente, pedagogia, que visam controlar a definição do que significa ser educado integralmente.

Nessas condições, é imperativo considerar que as redes de política, como uma nova forma de governança, causam uma interdependência entre os atores na busca por resoluções eficazes para os problemas insolucionáveis da sociedade e formam um mercado de autoridades. No caso da Paraiba, a autoridade se tornou o ICE, ao ser acolhido como instituição para direcionar o conhecimento, a gestão, o currículo, o processo de ensinoaprendizagem, a didática, a prática docente e a avaliação, ou seja, a prática pedagógica mais adequada para a educação paraibana (BALL, 2014).

Tal circunstância nos remete ao fato de que as relações entre o Estado, a Economia e a Sociedade Civil

\footnotetext{
[...] estão ficando turvas; há novas vozes nas conversas sobre as politicas e novos canais por meio dos quais os discursos introduzem o pensamento sobre políticas; e a proliferação nacional e globalmente, de redes políticas compostas de organizações "operacionalmente autônomas", mas "estruturalmente acopladas". (BALL, 2014, p. 34).
}

Não podemos negar que, pensando globalmente, vemos que existe uma multiplicidade de agências multilaterais e Organizações não Governamentais (ONGs) que têm 
interesses e exercem influência sobre as políticas de forma que reduzem a capacidade do Estado de gerenciar suas políticas e sistemas de ensino, especialmente os estados pequenos e em desenvolvimento. Para lidar com essa ineficiência, novas redes são constituídas para dar fluxo a novos discursos e conhecimentos, que vão ganhando legitimidade e credibilidade.

Essas redes constituídas operam práticas e impõem tecnologias às instituições de ensino e sobre elas, tornando corriqueiros princípios neoliberais, que se apresentam em nossa linguagem, ações, propósitos e tomadas de decisões e moldam, inclusive, nossas relações sociais. Essas práticas pretendem incluir no currículo "métodos e valores do setor privado e aprender a reformar-se." (BALL, 2014, p. 65). As tecnologias morais serão responsáveis por incluir, ainda no currículo, características da metagovernança (metaorganização, metatroca, meta-hierarquia), que, ao se interligar à performatividade, serão indispensáveis como componentes de gerência e de empreendedorismo.

Depois de realizar a pesquisa, situamos, a seguir, o ICE por meio da representação da rede de atores que atuam acopladas ao instituto, como mostra o Diagrama 1, em que os financiadores estão circunscritos em balões cinza, e os think tanks (laboratório de ideias) são os demais balões que se dividem entre parceiros e parceiros técnicos do ICE.

Diagrama 1 - Rede de influência e fluxo do Instituto de Corresponsabilidade pela Educação

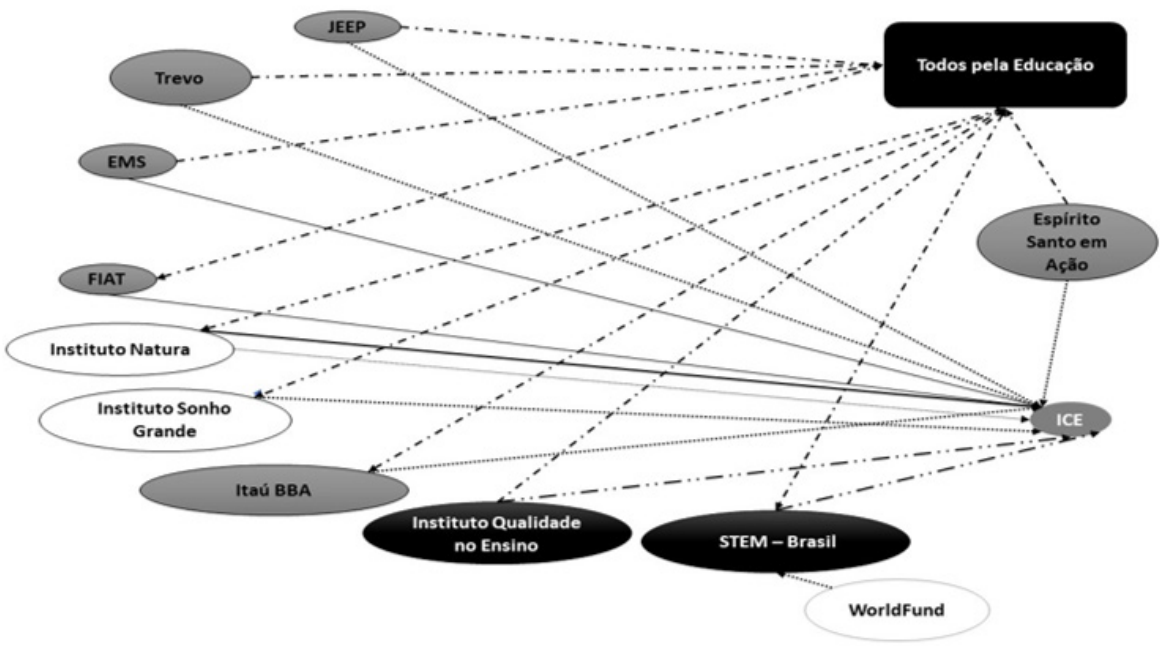

Legenda

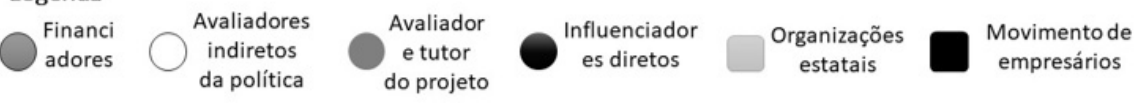

Fonte: os autores. 
Essa rede é uma representação inicial da heterarquia que, segundo Ball (2013, p. 178), "[...] é uma forma de organização, algo entre hierarquia e rede, que aproveita diferentes ligações horizontais as quais permitem que diferentes elementos do processo político cooperem (e/ou se complementam) enquanto individualmente utilizam diferentes critérios de sucesso [...]"

As heterarquias exercem uma privatização endógena e exógena; a primeira é responsável por imprimir uma eficiência às organizações estatais, dando-lhes um tom empresarial; já a segunda é a em que as organizações estatais são substituídas por financiadores privados, voluntários ou empresas sociais. Assim, o que representamos no Diagrama 1 é uma camada da rede, pois cada instituição que está ligada ao ICE tem outras conexões com outros grupos, como, por exemplo, o Instituto Natura, que está ligado aos Institutos Lina Galvani, Ayrton Senna, Unibanco, Positivo, Votorantim, Humanize, além das Fundações Lemann, Roberto Marinho, Telefônica Vivo, entre outros. Todavia, a rede, ou partes dela, conta com grupos e/ou indivíduos financiadores e comerciantes de ideias que vendem suas soluções no mercado político e/ou acadêmico, como faz a UFSCar, que é um dos parceiros do Instituto Natura.

Precisamos considerar que, de forma experimental e estratégica, a governança acontece por meio de uma rede ampla de instituições que financiam, mas também instituem diretrizes para as políticas entre as comunidades políticas, o que "[...] gera nova capacidade de governar e aumenta a legitimidade le credibilidade]. Essas novas redes políticas trazem alguns novos tipos de atores para o processo político e validam novos discursos das políticas [...]" (BALL, 2013, p. 179-180).

A legitimidade e a credibilidade do ICE podem ser constatadas em seu site, que mostra a amplitude de sua rede, que já alcança 19 estados do Brasil e um total de 1.335 escolas públicas. Entre os estados está o Ceará, que teve os maiores índices no IDEB, e dos Municípios destacamos o de Sobral, que têm provocado uma mobilidade da política para o âmbito nacional.

Para Ball (2014), o termo mobilidade substitui o termo transferência e é a capacidade que a política tem de se mover por meio das redes políticas sendo (re)contextualizadas e envolvendo participantes, interesses, compromissos, finalidades e influências diversas, que são unidos por um conjunto de discursos legitimados e que circulam na rede.

Assim, instituída a parceria com o ICE em 2015, em 2016, começaram a ser implantadas oito Escolas Cidadãs Integrais que, a partir das orientações do ICE e de financiadores, deveriam ser quatro escolas novas, que seriam acompanhadas e treinadas. Contrário às orientações do ICE, o Entrevistado 2 relatou que o Estado da Paraíba adotou os seguintes critérios: quatro escolas novas (que seriam as monitoradas pelo ICE) e quatro escolhidas, das que já existiam na rede (que seriam monitoradas pela CEEI), em decorrência dos baixos índices nas avaliações externas, e a comunidade escolar deveria aceitar a mudança no modelo pedagógico. Por fim, ambos os Entrevistados afirmaram que outro critério era de que as escolas deveriam estar 
localizadas em regiões com elevado índice de violência, pois a expectativa era de que tais escolas mudariam essa realidade, sendo esse último critério o mais questionado pelo instituto e pelos financiadores, uma vez que entendiam que essas escolas seriam tendenciosas a não evoluírem nos resultados.

A parceria é uma relação que o Instituto denomina de corresponsabilidade, para implantar e desenvolver a política, e o ICE mobiliza e potencializa diferentes atores da rede. ${ }^{6}$ A Figura 1 ilustra como os sujeitos e as instituições envolvidos no processo de implantação colaboram com essa ideia de corresponsabilidade.

Figura 1 - Representação da corresponsabilidade com a atuação da proposta pedagógica

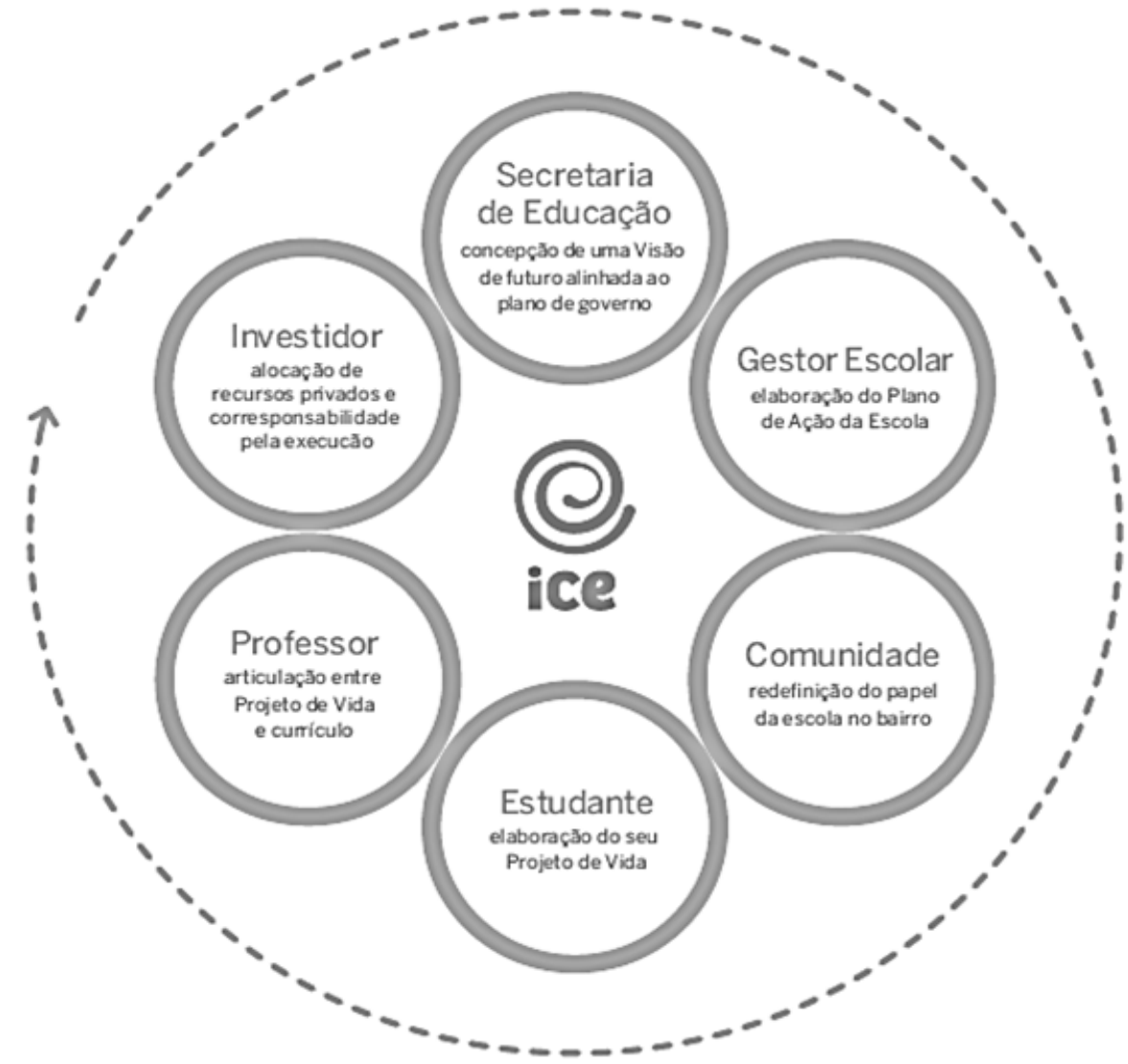

Fonte: Instituto de Corresponsabilidade pela Educação (2019).

6 Registramos que o documento formal da parceria entre o Governo do Estado da Paraíba e o Instituto de Corresponsabilidade pela Educação não foi disponibilizado, porém tivemos acesso a documentos de parcerias firmadas em outros estados do Brasil com o mesmo teor. 
Como demonstra a Figura 1, a parceria de corresponsabilidade funcionou de forma que o ICE ficou responsável pela "articulação de fundações empresariais, não cobrando nada do Estado e pela execução do modelo pedagógico e a avaliação de algumas escolas." (Entrevistado 1, informação verbal). Explicando de forma mais detalhada, o Entrevistado 2 (2019) disse: "[...] são os parceiros que patrocinam o instituto para que eles trabalhem dentro desses estados [...] quem patrocina aqui é o Instituto Sonho Grande, Natura, então o BBA vem mais para as escolas técnicas, então têm os parceiros que garantem que o ICE permaneça aqui." (informação verbal).

0 Entrevistado 2 ressaltou que o ICE começou tutelando

\begin{abstract}
oito escolas, depois bancaram, acho que, 20 e poucas, e a gente ampliou mais do que eles queriam, e eles dizendo "mas rapaz isso não dá certo", eu digo dá certo, e hoje nós tamo (sic) com 153 e eles ficaram lá atrás, ou seja, a gente avançou mais do que aquilo que um [tutor] estava nos orientando em relação ao modelo de escola. (informação verbal).
\end{abstract}

0 Entrevistado 1 lembra que, de oito, a ampliação foi para 33. Isso quer dizer que o Estado começou a superar os limites impostos pelo ICE e a se responsabilizar por outras escolas, para além dos limites do instituto. Assim surgiu a necessidade de uma comissão para dar continuidade a esse processo de expansão. Todavia, o tempo de estadia do ICE é de três anos, como ilustra o Fluxograma 1, que apresenta o que o Instituto chama de "passo a passo 'da parceira à passagem do bastão': ciclo de três anos". 
Fluxograma 1 - Ciclo de três anos da parceria com o ICE

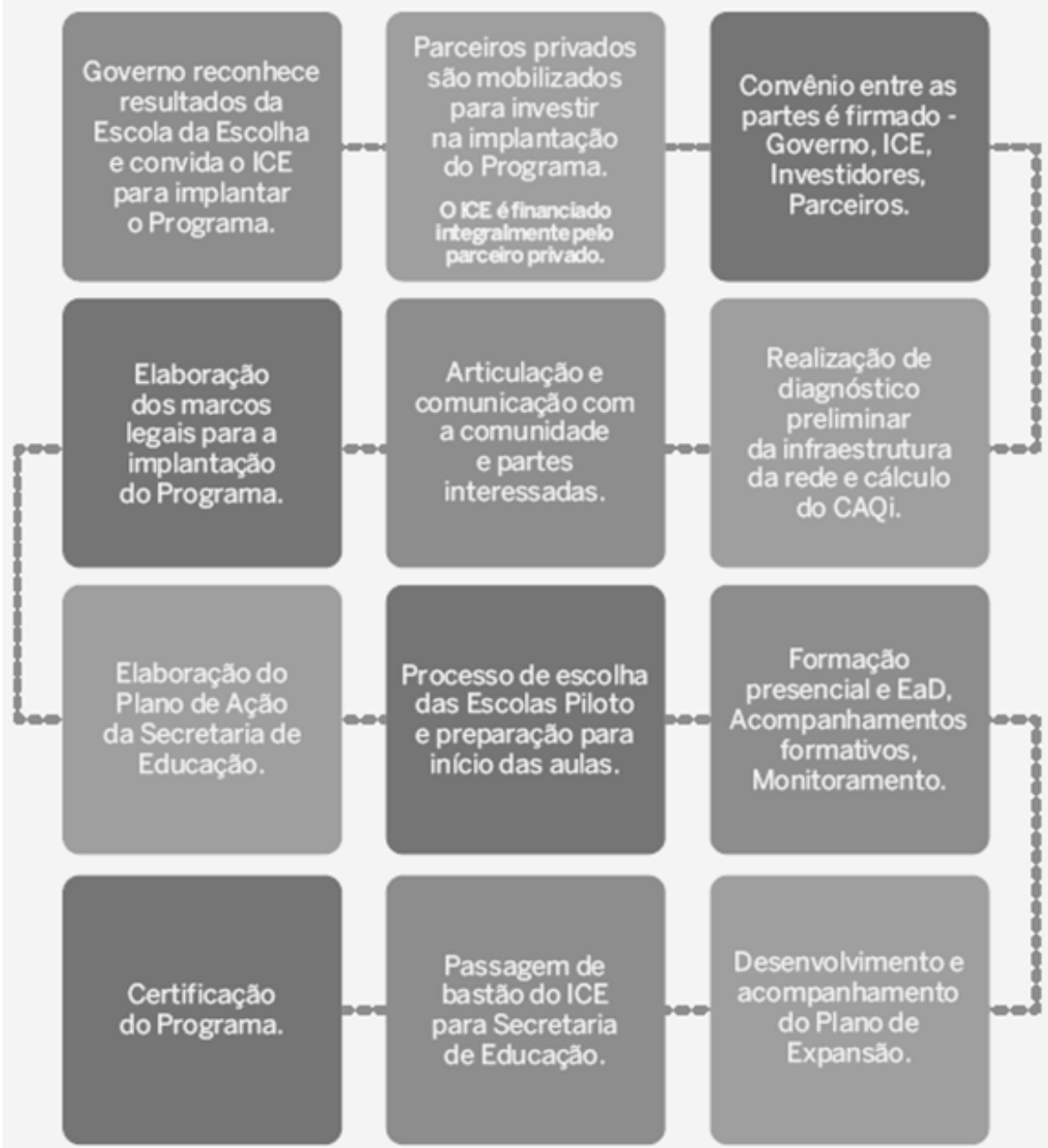

Fonte: Instituto de Corresponsabilidade pela Educação (2019).

É importante considerar que, em virtude da sua abrangência e credibilidade, a Paraíba se interessou em se apropriar de um modelo que estava em evidência, com dados consolidados e que vinha sendo tido como referência. Como o modelo pernambucano e o cearense foram os escolhidos para melhorar a qualidade da educação pública, foi instituída uma parceria com o Instituto de Corresponsabilidade pela Educação (ICE), que passou a traçar prioridades, estratégias e formas de governar a educação, dando uma ênfase grande à reforma da gestão e da ação docente. Entregar a gestão da Educação paraibana ao ICE é, para Harvey (2008, p. १2), a confirmação de que "[...] o neoliberalismo se tornou hegemônico 
como modalidade de discurso e passou a afetar tão amplamente os modos de pensamento que se incorporou às maneiras cotidianas de muitas pessoas interpretarem, viverem e compreenderem o mundo."

É pertinente suscitar que a agenda da Educação Integral na Paraiba vem sendo construida desde as iniciativas do Governo Federal, com Programas como o Mais Educação (Portaria Interministerial n. 17/2007 (BRASL, 2007) e o Decreto n. 7.083/2010 (BRASIL, 2010). Como nos lembram Bowe, Ball e Gold (1992, p. 21), as políticas são resultados de "embates e compromissos" que só se consolidaram no segundo mandato do Governo Ricardo Coutinho. Essas iniciativas apresentavam um conjunto de atores que constituíam a rede de políticas que vinham construindo o discurso sobre educação integral no Brasil e, consequentemente, na Paraiba, em que estavam presentes as diretrizes neoliberais de um Estado mínimo, que se abstém de diversos setores, entre eles os das políticas sociais, e contribui para que exista por meio de uma autorregulação. Essa necessidade vem de um processo de desconstrução do Estado que é considerado arcaico e ineficiente e necessita de um setor privado, moderno e eficiente.

Não podemos entender o "Estado mínimo" como a negação ou extinção do Estado, que se torna, nos ditames neoliberais, um meio para garantir o predomínio dos valores de mercado (neoliberais), mas também representa para os neoconservadores uma forma de manter as tradições sociais, políticas, econômicas, religiosas e culturais construídas e testadas ao longo do tempo, sem nenhum aprofundamento crítico, ou seja, a manutenção de valores e costumes que estão ameaçados pela ideia de um igualitarismo que coloca em risco a família, a igreja e a comunidade e enfraquece os laços que são naturais (MOLL, 2015). Constatamos isso no conjunto de documentos emitidos pelo Estado, que dão substância à ação das instituições privadas na Rede Estadual de Ensino da Paraiba e institucionalizam a Comissão Executiva de Educação Integral, que visa operacionalizar a implantação, a regulação e o funcionamento do Programa de Educação Integral, em seu art. 23, possibilitando que a SEECT firme convênios, termos de parceria ou cooperação e instrumentos congêneres para executar ações em seu favor.

Não podemos negar que essa iniciativa está subscrita na rede internacional, como nos mostraram as análises documentais, que têm como atores internacionais da rede o Banco Mundial (BM), a Organização para a Cooperação e o Desenvolvimento Econômico (OCDE) e a Organização das Nações Unidas para a Educação, a Ciência e a Cultura (Unesco). Esses atores vêm instituindo fluxos e influências na construção do discurso de Educação Integral, produzindo políticas junto a instituições governamentais, como, por exemplo, o Ministério da Educação (MEC); o antigo Ministério do Desenvolvimento Social e Combate à Fome (MDS), que, em 2019, passou a compor o Ministério da Cidadania e foi denominado Secretaria Especial do Desenvolvimento Social; o antigo Ministério do Esporte que, em 2019, passou a compor 
- Ministério da Cidadania e foi denominado Secretaria Especial do Esporte; o Ministério da Ciência, Tecnologias, Inovações e Comunicações (MCTIC), antigo Ministério da Cultura (MC), hoje Secretaria Especial de Cultura, que, em 2019, passou a ser vinculada ao Ministério do Turismo; o Instituto Nacional de Estudos e Pesquisas Educacionais Anísio Teixeira (Inep), a Controladoria Geral da União (CGU) e o Conselho Nacional de Educação (CNE).

Nessa primeira etapa da análise das influências, seguindo o método de Bowe, Ball e Gold (1992), para compreender o fluxo de ideias entre a rede de políticas que está envolvendo a circulação internacional de ideias, predominou o instituído pelo Instituto Sonho Grande, Instituto Qualidade no Ensino, Wordfun, entre outros. No caso da Paraiba, o acordo de cooperação foi celebrado com o Instituto de Corresponsabilidade da Educação, com o Itaú BBA e o Instituto Sonho Grande. Esses dois últimos são os financiadores.

Diagrama 2 - Rede de influências e fluxos da Política de Educação Integral da Paraiba

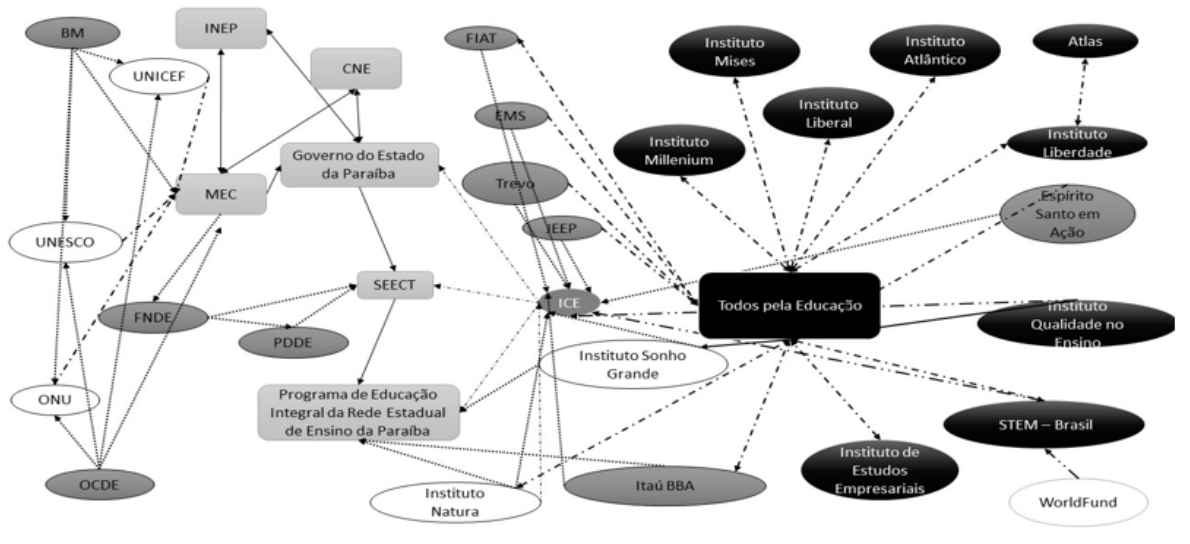

Legenda

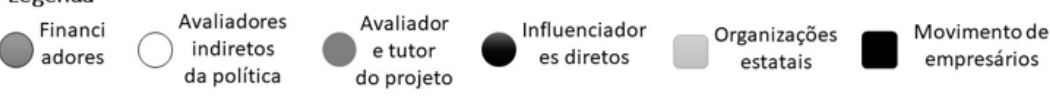

Fonte: os autores.

Seguindo para a segunda via de análise, deparamo-nos com um conjunto de financiadores que vêm instituindo algumas imposições no processo de construção do discurso sobre as políticas e na criação dos textos sobre ela, como, por exemplo, o Fundo Nacional do Desenvolvimento da Educação (FNDE), o Programa Dinheiro Direto na Escola (PDDE) e as instituições privadas que, utilizando-se da filantropia, investem na educação por meio do ICE, como Itaú BBA, Instituto Natura, Jeep, Trevo Tecnologias Sociais, EMS, FIAT Chrysler, Espírito Santo em Ação e Instituto Sonho Grande. Essa relação de financiadores reproduz na educação um modelo de mercado de um sistema mundial, mergulhado no modelo neoliberal. 
Mais especificamente, causam efeitos das forças de mercado nas escolas e nos pais e sobre os benefícios do mercado para os pais. Trata-se da ideologia e das práticas do mercado da educação, como se observa na proposta pedagógica da escola muito fortemente nos ideários de protagonismo, empreendedorismo, valores e projeto de vida, todos com foco no desenvolvimento de sujeitos aptos às necessidades do mercado de trabalho. Para os idealizadores do Instituto,

\footnotetext{
[..] a escola é o lugar onde são providas condições fundamentais para a formação do jovem: uma formação acadêmica de excelência, uma sólida formação em valores e um desenvolvimento de competências essenciais para atuar diante dos desafios trazidos pelo Século XXI. (LIVRETO INSTITUCIONAL ICE, [20--2], p. 9).
}

A citação expressa o que a rede que influencia a política de educação integral na Paraíba considera como "condições fundamentais" que devem alicerçar a educação, ou seja, "a formação acadêmica", "uma sólida formação em valores" e "o desenvolvimento de competência". Não nos deteremos em aprofundar as discussões sobre a formação acadêmica das instituições que aderiram ao Programa Escola Cidadã Integral no Estado, o que já vem sendo estudado por Rodrigues (2019), Honorato, Pereira e Rodrigues (2019), Honorato, Rodrigues e Albino (2019) e Silva, Nascimento e Rodrigues (2018). Destacamos, apenas, que o modelo adotado estabelece uma "sólida formação em valores", definido no Caderno Tecnologia de Gestão Educacional. Porém, os "valores devem estar naquilo em que todas as pessoas envolvidas com a Escola acreditam e a partir dos quais nortearão as suas decisões e a realização dos seus trabalhos." (ZIMMERMAN, 2015, p. 25).

Ora, com a identificação dos financiadores e dos parceiros do ICE, conforme apresentado no Diagrama 2, infere-se que os valores instituídos apresentam perspectivas ideológicas mercadológicas e neoconservadoras relacionadas a proposições globais vinculadas à Rede Atlas, ao Instituto Millenium, ao Instituto Liberal, ao Instituto Liberdade, ao Instituto Atlântico, ao Instituto Mises e ao Instituto de Estudos Empresariais, "que formam canais locais a partir de uma rede internacional de relações para a difusão de conhecimento e de informação - 'neoliberalismo tamanho único'" (BALL, 2014, p. 62) -, cuja intenção é formar um pensamento de governos nacionais.

0 mercado, como uma alternativa política para a educação pública única, é claramente o foco da política educacional defendida pelos financiadores. Por isso corre o risco de se tornar inatacável. Na política educacional, existe uma ideologia bem-estabelecida, poderosa e complexa do mercado e uma cultura de escolha, que são sustentadas por 
idealizações sobre o funcionamento dos mercados e os efeitos da escolha dos pais e dos incentivos "lucrativos" na educação.

Por fim, a representação das relações e dos vínculos das instituições/parceiros, supracitada no Diagrama 2 do ICE, é o nó central da rede, em vez da política, que é foco do estudo em questão, o que só fortalece a concepção de que as políticas educacionais são pensadas e implantadas a partir da conectividade entre atores distintos, o que as torna um meio para a atuação de redes. No caso específico deste estudo, a rede formada a partir do ICE expressa o emaranhado de proposições que cercam o Programa de Educação Integral da Paraíba, em que os atores ligados ao Todos pela Educação, em círculos cinza e preto, são os que influenciam mais diretamente as ações, representados na rede por meio de instituições ligadas à gestão, ao financiamento ou à avaliação do projeto.

\section{CONSIDERAÇÕES FINAIS}

Não pretendemos, neste texto, analisar, individualmente, cada relação constituída na rede que forma o ICE nem apontar as complexas e multifacetadas atividades que cada membro da rede representa por meio das ligações abordadas, mas indicar os fluxos e as influências que atuam de forma direta e indireta na Política de Educação Integral na Paraíba. Esses aspectos refletem uma multiplicidade de relações, intenções, encontros interpessoais e ocasionais de atores sociais e instituições que veem na educação e na governamentalidade de crianças, jovens e adultos uma oportunidade de atuação econômica para uma sociedade cada vez mais mercadológica e desigual.

Constatamos que existe uma influência marcante de múltiplos atores, nacionais e internacionais, na construção da política de educação integral da Paraíba, cuja gênese se configurou na parceria com uma instituição que pertence a uma rede mais ampla de empresários que estão se expandindo pelo território nacional de forma surpreendente, disseminando valores e concepções que sustentam práticas educativas caracterizadas como neoliberais e neoconservadoras.

As policy networks, para Ball (2014) e para os autores deste trabalho, são teias políticas e relações constituídas justamente por meio dessas parcerias estabelecidas entre o Estado, diferentes organismos sociais e o setor privado. Essas "redes têm sido configuradas com a atuação efetiva de parcerias público-privadas, pautadas nos discursos de filantropia e em um novo modelo da indústria do serviço educacional conduzido por gestores empresariais e educacionais." (SILVA; SOUZA; RICHTER, 2015, p. 654). 
Assim, percebemos o quanto é importante considerar todos os atores como peças-chave para que possamos refletir sobre o desenvolvimento da Política de Educação Integral da Paraiba, o que exige que as pesquisas sobre políticas educacionais não se restrinjam à consideração do contexto local, do regional, do nacional ou do internacional, mas das relações entre essas arenas.

A partir dos resultados deste estudo, podemos inferir que as instituições, os parceiros e os financiadores que atuam na rede que constitui o ICE veem na educação uma oportunidade de investir, de fazer negócios globais e de economização da educação para garantir a criação de um novo perfil de aluno (futuro profissional), pronto para atender às demandas do mercado de trabalho, por meio de uma cultura mundial de escolarização.

Destacamos que a parceria com o Instituto de Corresponsabilidade pela Educação (ICE) possibilitou uma gestão da educação integral com traços neoliberais e neoconservadores com a padronização de escolas e a homogeneização dos discentes, utilizando o discurso de uma educação de boa qualidade, capaz de formar sujeitos sociais com oportunidades iguais.

Observamos que as bases pedagógicas dessa rede defendem $\circ$ avanço econômico e o resgate de princípios e valores com vistas a consolidar um currículo que forme profissionais para atuarem no mercado de trabalho e a fortalecer o pensamento que reduz a educação a uma mera apropriação de competências e habilidades sem a formação de sujeitos autônomos, mas subordinados ao capital econômico.

Portanto, a nova forma de governança encontrada no Programa Escola Cidadã Integral confirma a existência de um projeto de educação com bases neoliberais e neoconservadoras, que atuam por meio dos projetos de vida, do protagonismo e do empreendedorismo, visando criar um novo modelo para o jovem que atenda às demandas do mercado.

\section{REFERÊNCIAS}

APLLE, M. W. Educando à direita: mercados, padrões e desigualdades. Tradução: Dinah de Abreu Azevedo. Revisão técnica: Antônio Eustáquio Romão. São Paulo: Cortez; Instituto Paulo Freire, 2003. (Biblioteca Freiriana, v. 5).

BALL, S. J. Educação global S. A.: novas redes políticas e o imaginário neoliberal. Tradução: Janete Brindon. Ponta Grossa: UEPG, 2014.

BALL, S. J.; MAGUIRE, M.; BRAUN, A. Como as escolas fazem as políticas: atuação em escolas secundárias. Tradução: Bridon Janete. Ponta Grossa: Editora UEPG, 2016. 
BALL, S. J. Novos Estados, nova governança e nova política educacional. In: APLLE, M. W.; BALL, S. J.; GANDIN, L. A. Sociologia da educação: análise internacional. Tradução: Cristina Monteiro. Revisão: Luís Armando Gondim. Porto Alegre: Penso, 2013. p. 177-189.

BALL, S. J. Vozes/Redes políticas e um currículo neoliberal global. In: PEREIRA, M. Z. C. et al. (org.). Diferença nas políticas de currículo. João Pessoa: Editora Universitária da UFPB, 2010. p. 21-45.

BERNSTEIN, B. On the classification and framing of educational knowledge. In: YONG, M. F. D. (ed.). Knowledge and control. London: Collier-Macmillan, 1971. p. 47- 69.

BOBBIO, N.; MATTEUCCI, N.; PASQUINO, G. (ed.). Dicionário de política. 5. ed. Brasília: Editora Universidade de Brasília, 2000.

BOMENY, H. A escola no Brasil de Darcy Ribeiro. Em Aberto, v. 22, n. 80, p. 109-120, abr. 2009. D0l: https://doi.org/10.24109/2176-6673.emaberto.2li80.2224. Disponivel em: http://rbep.inep.gov.br/ojs3/ index.php/emaberto/article/view/2422. Acesso em: 5 abr. 2019.

BONAZZI, T. Conservadorismo. In: BOBBIO, N.; MATTEUCCl; N.; PASQUINO, G. (org.). Dicionário de poĺtica. Brasília, DF: Editora da UnB; São Paulo: Imprensa Oficial, 2000. v. 1. p. 242-246.

BÖRZEL, T. Qué tienen de especial los policy networks? Explorando el concepto y su utilidad para el estudio de la gobernación europea. [S. L.: s. n.], 1997. Disponível em: http://seneca.uab.es/antropologia/redes/redes.htm. Acesso em: 12 jun. 2019.

BOWE, R.; BALL, S. J.; GOLD, A. Reforming education and changing schools: case studies in Policy Sociology. London: Routledge, 1992.

BRASIL. Decreto n. 6.094, de 24 de abril de 2007. Dispõe sobre a implementação do Plano de Metas Compromisso Todos pela Educação, pela União Federal, em regime de colaboração com Municípios, Distrito Federal e Estados, e a participação das familias e da comunidade, mediante programas e ações de assistência técnica e financeira, visando a mobilização social pela melhoria da qualidade da educação básica. Diário Oficial da União, Brasília, DF, 25 abr. 2007. Disponível em: http://www.planalto. gov.br/ccivil_03/_Ato2007-2010/2007/Decreto/D6094.htm. Acesso em: 8 jul. 2019.

BRASIL. Decreto n. 7.083, de 27 de janeiro de 2010. Dispõe sobre o Programa Mais Educação. Diário Oficial da União, Brasília, DF, 27 jan. 2010. Disponivel em: http://www.planalto.gov.br/ccivil_03/_ Ato2007-2010/2010/Decreto/D7083.htm. Acesso em: 8 jul. 2019.

BURKE, E. Reflexões sobre a revolução na França. Tradução: Renato de Assumpção Faria. 2. ed. São Paulo: UNB, 1982. 
CARVALHO, L. E. P.; RODRIGUES, R. B. F. Gerencialismo privado na educação pública: o Instituto de Corresponsabilidade pela Educação (ICE) na Paraiba. In: ENCONTRO NACIONAL DE PRÁTICA DE ENSINO DE GEOGRAFIA: POLITICAS, LINGUAGENS E TRAJETÓRIAS, 14., 2019. Anais [...] São Paulo: Unicamp, 2019. p. 42614274. Disponivel em: https://ocs.ige.unicamp.br/ojs/anais14enpeg/article/view/3237/3102. Acesso em: 15 out. 2019.

DARDOT, P.; LAVAL, C. A nova razão do mundo - ensaio sobre a sociedade neoliberal. Tradução: Mariana Echalac. 1. ed. São Paulo: Boitempo, 2016.

FLEURY. S. Redes de políticas: novos desafios para a gestão pública. Administração em Diálogo, n. 7, p. 77-89, 2005. D0l: https://doi.org/10.20946/rad.v7il.671. Disponivel em: https://revistas.pucsp.br/index. $\mathrm{php} / \mathrm{rad} /$ article/view/671. Acesso em: 15 out. 2019.

GOLDWATER, B. The Conscience of a Conservative. United States of America: Start Publishing, 2009.

GOUVEIA, M. J. A. Educação integral com a infância e a juventude. Cadernos Cenpec, n. 2, p. 77-85, 2006. DOl: https://doi.org/10.18676/cadernoscenpec.vli2.128. Disponível em: http://www.cadernos. cenpec.org.br/cadernos/index.php/cadernos/article/viewFile/128/160. Acesso em: 15 out. 2019.

HABERMAS, J. Neoconservative culture criticismo in the United States and West Germany: na intelectual movement in two political cultures. In: BERNSTTEIN, R. J. (ed.). Habermas and modernity. Cambridge: Polity Press, 1985. p. 75-89.

HARVEY, D. 0 neoliberalismo: história e implicações. São Paulo: Edições Loyola, 2008.

HONORARO, R. F. S. et al. Como as escolas fazem as politicas: atuação em escolas secundárias (Resenha). Revista Teias, v. 20, n. 56, p. 203-213, jan./mar. 2019. D0l: https://doi.org/10.12957/ teias.2019.38727. Disponivel em: https://www.e-publicacoes.uerj.br/index.php/revistateias/article/ view/38727. Acesso em: 15 maio 2019.

HONORATO, R. F. S.; PEREIRA, M. Z. C.; RODRIGUES, A. C. S. Currículo e socioeducação: ataques, lutas e resistências na Paraiba. In: REUNIĨO NACIONAL DA ASSOCIAÇÃO NACIONAL DE PÓS-GRADUAÇÃO E PESQUISA EM EDUCAÇÃO., 39, Niterói. Anais [...] Niterói: ANPed, 2019. p. 1-6. Disponível em: http://anais.anped.org. br/ę_ga=2.206656851.1511877467.1580751608-509247639.1540931280. Acesso em: 12 dez. 2019.

HONORATO, R. F. S.; RODRIGUES, A. C. S.; ALBINO, A. C. A. Educação integral no sistema socioeducativo: o currículo como redes de significações discursivas. Revista Teias, v. 20, p. 334-350, 2019. D0l: https:// doi.org/10.12957/teias.2019.47463. Disponível em: https://www.e-publicacoes.uerj.br/index.php/revistateias/article/view/29313. Acesso em: 15 dez. 2019.

INSTITUTO DE CORRESPONSABILIDADE PELA EDUCAÇÃO. Atuação. Recife: ICE, 2019. Disponivel em: http:// icebrasil.org.br/atuacao. Acesso em: 10 ago. 2019. 
INSTITUTO DE CORRESPONSABILIDADE PELA EDUCAÇÃO. Livreto institucional. Recife: ICE, [20--2]. Disponível em: http://icebrasil.org.br/wp-content/uploads/2017/05/Livreto_Digital_Institucional.pdf. Acesso em: 10 ago. 2019.

KIRK, R. The conservative mind: from Burke to Santayana. Chicago: Henry Regnery Company, 1953.

MARCONDES, M. L.; FREUNDE, C.; LEITE, V. F. Uma nova abordagem ao estudo das políticas educacionais. Práxis Educativa, v. 12, n. 3, p. 1028-1034, set./dez. 2017. Disponivel em: https://www.revistas2.uepg. br/index.php/praxiseducativa/article/view/9643/5577. Acesso em: 20 out. 2019.

MARSH, D.; RHODES, R. A. Policy networks in British politics. A critique of existing approaches. In: RHODES, R. A.; MARSH, D. Policy networks in British government. Oxford: Clarendon Press, 1992. p. 1-26.

MOLL, R. Diferenças entre neoliberalismo e neoconservadorismo: duas faces da mesma moeda? Sem diplomacia, 23 jul. 2015. Disponivel em: http://unesp.br/semdiplomacia/opiniao/ 2015/43. Acesso em: 12 jun. 2019.

PARÁBA. Decreto n. 36.408, de 30 de novembro de 2015. Cria a Escola Cidadã Integral, institui o Regime de Dedicação Docente Integral - RDDl e dá outras providências. Diário Oficial do Estado da Paraiba, João Pessoa, 1 dez. 2015a. Disponivel em: http://static.paraiba.pb.gov.br/2015/12/Diario-Oficial-01-12-2015.pdf. Acesso em: 10 ago. 2019.

PARÁ́BA. Decreto n. 36.409, de 30 de novembro de 2015. Cria a Escola Cidadã Integral Técnica, institui - Regime de Dedicação Docente Integral - RDDl e dá outras providências. Diário Oficial do Estado da Paraíba, João Pessoa, 1 dez. 2015b. Disponível em: http://static.paraiba.pb.gov.br/2015/12/Diario-Oficial-01-12-2015.pdf. Acesso em: 10 ago. 2019.

PARÁBA. Lei n. 11.100, de 6 de abril de 2018. Cria o Programa de Educação Integral, composto por Escolas Cidadãs Integrais - ECl, Escolas Cidadãs Integrais Técnicas - ECIT e Escolas Cidadãs Integrais Socioeducativas - ECIS e institui o Regime de Dedicação Docente Integral - RDDl e dá outras providências. Diário do Poder Legislativo, João Pessoa, 12 abr. 2018a. Disponível em: http://www.al.pb.leg.br/ wp-content/uploads/2018/04/DPL-12.04.2018.pdf. Acesso em: 5 ago. 2019.

PARAíBA. Lei n. 11.314, de 11 de abril de 2019. Altera a Lei n 11.100, de 06 de abril de 2018, que cria o programa de educação integral. Diário Oficial do Estado da Paraiba, 12 abr. 2019. Disponível em: https:// auniao.pb.gov.br/servicos/arquivo-digital/doe/2019/abril/diario-oficial-12-04-2019.pdf. Acesso em: 11 nov. 2019.

PARAíBA. Medida Provisória n. 267, de 7 de fevereiro de 2018. Cria o Programa de Educação Integral, composto por Escolas Cidadãs Integrais - ECl, Escolas Cidadãs Integrais Técnicas - ECIT e Escolas Cidadãs Integrais Socioeducativas - ECIS e institui o Regime de Dedicação Docente Integral - RDDI e dá outras providências. Diário Oficial do Estado da Paraíba, João Pessoa, 9 fev. 2018b. Disponível em: http://static.paraiba.pb.gov.br/2018/02/Diario-Oficial-09-02-2018.pdf. Acesso em: 10 ago. 2019. 
RHODES, M. L. Ethical dilemmas in social work practice. London: Routledge; Kegan Paul, 1986.

RHODES, R. A. W. Beyond Westminster and Whitehall: the subcentral governments of Britain. London: Allen \& Unwin, 1988.

RODRIGUES, A. C. S. Escola Cidadã Integral: proposições curriculares para jovens do Ensino Médio. Revista Espaço do Currículo, v. 12, n. 1, p. 139-152, jan./abr. 2019. D0l: https://doi.org/10.22478/ufpb.1983-1579.2019v12n1.41984. Disponível em: https://periodicos.ufpb.br/index.php/rec/article/view/ufpb.1983-1579.2019v12n1.41984. Acesso em: 18 set. 2019.

SANTOS, H. Perspectivas contemporâneas para a constituição de redes de politicas públicas. Civitas - Revista de Ciências Sociais, v. 5. n. 1, p. 59-68, jan./jun. 2005. D0l: http://dx.doi.org/10.15448/19847289.2005.1.34. Disponível em: http://revistaseletronicas.pucrs.br/ojs/index.php/civitas/article/ view/34. Acesso em: 18 set. 2019.

SCHNEIDER, V. Redes de políticas públicas e a condução de sociedades complexas. Civitas - Revista de Ciências Sociais, v. 5. n. 1, p. 29-58, jan./jun. 2005. D0l: https://dx.doi.org/10.15448/1984-7289.2005.1.33. Disponivel em: https://revistaseletronicas.pucrs.br/ojs/index.php/civitas/article/view/33. Acesso em: 18 set. 2019.

SHIROMA, E. 0. Networks in action: new actors and practices in education policy in Brazil. Journal of Education Policy, v. 29, n. 3, p. 323-348, 2014. D0l: https://doi.org/10.1080/02680939.2013.831949 . Disponivel em: https://www.tandfonline.com/doi/abs/10.1080/02680939.2013.831949. Acesso em: 18 set. 2019.

SILVA, A. C.; NASCIMENTO, A. I. N.; RODRIGUES, A. C. S. Relatos de pesquisa em educação de tempo integral: desafios para a efetivação de uma proposta freireana. In: LOPES, E. J.; AMORIM, R. M. do (org.). Paulo Freire: culturas, ética e subjetividade no ensinar e aprender. 1. ed. João Pessoa: Editora do CCTA, 2018. p. $175-198$.

SILVA, M. V.; SOUZA, V. A.; RICHTER, L. M. Educação e classes sociais: as "redes de políticas públicas" e o ethos mercantil na esfera pública. ETD: Educação Temática Digital, v. 17, n. 3, p. 653-672, 2015. D0l: https://doi.org/10.20396/etd.v17i3.8638251. Disponivel em: https://periodicos.sbu.unicamp.br/ojs/index. php/etd/article/view/8638251. Acesso em: Acesso em: 18 out. 2019.

SPRING, J. Corporações globais querem usar as escolas para moldar o homem para o Mercado. Tradução: Ana Júlia Galvan. Campinas, SP: Vide Editorial, 2018.

SÜSSEKIND, M. L. Entrevista. Educação em Pauta, ano V, v. 1, p. 4-12, ago. 2018. Disponível em: http:// adcpii.com.br/wp-content/uploads/2018/07/ebook_revista_6.pdf. Acesso em: 11 nov. 2019. 
VIDAL, C. F. 0 movimento conservador norte-americano da década de 1950 e a percepção conservadora a respeito de sociedade, economia e política externa. TOM0, n. 23, p. 259-294, jul./dez. 2013. D0l: https://doi.org/10.21669/tomo.v0i23.2112. Disponivel em: https://seer.ufs.br/index.php/tomo/article/ view/2112. Acesso em: 18 out. 2019.

ZIMMERMAN, J. Caderno tecnologia de gestão educacional. 1. ed. Recife: Instituto de corresponsabilidade pela educação, 2015.

Endereço para correspondência: Departamento de Fundamentação da Educação, Centro de Educação, Campus I, Cidade Universitária João Pessoa, Castelo Branco, João Pessoa, Paraíba, Brasil; anaclaudia@ ce.ufpb.br

Roteiro, Joaçaba, U. 45, p. 1-32, jan./dez. 2020 | e21782 |E-ISSN 2177-6059 
